\title{
Integrated Model of Course Based on Edu-Communication and Psycho-Communication in Learning
}

\section{Almira Alves dos Santos, Carlos Frederico Alves, Eliane Monteiro Cabral Warren, Rozangela Maria de Almeida Fernandes Wyszomirska}

State University of Health Sciences of Alagoas (UNCISAL), Maceio, Brazil

Email:almira_alves@yahoo.com.br, fredpsi2@gmail.com,cabralwarren@yahoo.com.br, rozangelaw@yahoo.com.br

How to cite this paper: dos Santos, A. A., Alves, C. F., Warren, E. M. C., \& Wyszomirska, R. M. de A. F. (2019). Integrated Model of Course Based on Edu-Communication and Psycho-Communication in Learning. Creative Education, 10, 1080-1090.

https://doi.org/10.4236/ce.2019.106081

Received: April 22, 2019

Accepted: June 9, 2019

Published: June 12, 2019

Copyright $\odot 2019$ by author(s) and Scientific Research Publishing Inc.

This work is licensed under the Creative Commons Attribution-NonCommercial International License (CC BY-NC 4.0).

http://creativecommons.org/licenses/by-nc/4.0/

\begin{abstract}
Pedagogical practices should enable the development of skills and abilities common to the health professions for the training of general practitioners with a high technical and scientific level. The most important in the teaching-learning process is the joint construction of knowledge. Depending on the quality of communication is that access to the individual's conscious or unconscious will be done with greater or lesser potentiality. The present work presents an integrated model of course that is based on Edu-communication and Psycho-communication, and learning Psycho-communication, also using problematization about public health situations, as well as online learning design concepts. At the end of the course, students present educational products that contribute to the improvement or resolve of the identified health problem. The development of educational products was based on principles of behavioral theories: the structure of personality according to Eric Berne, the use of the senses, and neurolinguistics through the structuring of anchors. The graphic representation of the course shows a focus on Guidance and Support, Content and Activities, as well as Communication and Collaboration. The learning teaching process has a dynamicity capable of surprising us every day, every moment. Students demonstrate empathy with the course and present various educational products that have been available for use in health education.
\end{abstract}

\section{Keywords}

Health Education, Learning, Course

\section{Introduction}

The main learning theories that guided formal education are based on three 
main pillars: Behaviorism-theory that focused on the role that the mind plays in learning and focuses on what happens between the occurrence of the environmental stimulus and the student's response, from the concept of Skinner's operant conditioning (Skinner, 1968); Cognitivism-theory that deals with the understanding, storage and use of information, including the creation of a cognitive instructional design (Harasim, 2012); and Social Constructivism-based on the theories of various authors, such as Lev Vygotsky, John Dewey and Jean Piaget, seeking to explain teaching and learning as complex interactive social phenomena between teachers and students, where learning is a dynamic and the understanding of concepts or principles develops and becomes deeper over time (Picciano, 2017).

Several other theories or proposals have been derived from these, with their controversies and confluence points: the "Information Processing-based Learning Theory" is a variation on cognitivism and sees the human mind as a system that processes information according to a set of logical rules and proposed an information processing model that deals with how students acquire, encode, store (in short or long term memory) and retrieve information (Atkinson \& Shiffrin, 1968). Gardner's “Theory of Multiple Intelligences” (Gardener, 1983) proposes that intelligence is not only a unique intelligence, but consists of multiple intelligences used by individuals in different proportions to understand and learn about the world and suggests that intelligence design of multiple learning modalities allows students to be involved in the way they prefer, according to their interest or ability. Lin, Cranton and Bridglall (2005), postulated another theory, which concerns learning styles in which individuals learn differently, depending on their propensities and personalities. This theory uses studies on individual personality types that would influence various elements of human behavior, including learning.

However, the processes of social transformation that we have witnessed in the last decades and which are inevitably linked to vertiginous technological developments have been determining considerable changes in contemporary societies. The end of the nineteenth century represented a period of reformulation of educational principles, with the emergence of new ideas, some of which over time provoked a transformation in school and in the classroom. As a consequence of this movement, in the early twentieth century, universities began to become involved in teacher training, including the formation of colleges for training, while its faculty maintained as a rule of their training, postgraduate to doctorate, focused on research, and there is not much demand for their training in teaching methods (Quintas-Mendes \& Wyszomirska, 2018).

Since 2003, the National Health Department and the National Education Department in Brazil have launched policies for the reorientation of health education, with complementary actions to the National Curricular Guidelines, targeting health professionals in a perspective of the integration between teaching-service-community (Brasil, 2007, 2008), making use of interdisciplinarity, 
contextualization and autonomy, so that the students can develop general and specific skills and competences to health education and, thus, explore a knowledge that is present in the economic structure, political and cultural, permeated by the university and teachers (Moraes \& Costa, 2016). Pedagogical practices should enable the development of skills and abilities common to all health professions, for the training of general practitioners, in order to promote the perception that the living and working conditions of the population are decisive determinants in their health situation, considering also that the essence of a Pedagogical Project in the area of health should seek its social identity and be the link between the training exercise and the Brazil's Unified Public Health System. In this sense, the process of persistent critical reflection is essential in order to advance the transformation of pedagogical practice and curricular organization, using a diversified teaching-learning approach (Fernandes et al., 2012).

It is important to think of teaching as a communication process. Depending on the quality of communication, it is that access to the individual's conscious or unconscious will be done with greater or lesser potentiality. Within this parameter we need to understand how communication takes place, through which channels, how is the capture of information structured by the individuals. Based on these principles it is possible to use a more effective communication that will result in a greater potentiality in this process and consequently in the quality of learning. It is important to explore access to this individual, what channels are available and how to access them. Each individual is unique, acts and reacts in a way peculiar to each event.

The State University of Health Sciences of Alagoas-UNCISAL, after reforming its academic structure, in 2011, enabled the discussion and implementation of the integrated curriculum, which considers the presentation of content in an interconnected, student-centered way and with the use of active methodologies focused on the development of the student's ability to learn (Keller-Franco, Kuntze, \& Costa, 2012). This type of Curriculum was considered, based on Davini (1983), as “... a pedagogical plan and its corresponding institutional organization that dynamically articulates work and teaching, practice and theory, teaching and community". In order to contemplate these definitions, the curricula of the health courses were organized through integrative thematic axes, structured by curricular components common to the training of the diverse health professionals. Thus, an integrative course was created, available for all courses, called "Health Education", with an integrated model based in Edu-communication and learning Psycho-communication, also using problematization of public health situations, as well as online learning design concepts. At the end of the course, students present educational products that contribute to the improvement or resolve of the identified health problem. The development of educational products was based in principles of behavioral theories: the structure of personality according to Eric Berne, the use of the senses, and neurolinguistics through the structuring of anchors. 


\section{Representation of Course Structure}

Conole (2008), in reflecting on the potential of the new Web 2.0 technologies in pedagogical structures, stated that the use of technologies in education would be in a technologically deterministic direction, and there is a need to combine the possibilities of using the tools with what they could offer for learning.

In 2013, Conole, when discussing benefits in the elaboration of learning designs, concluded that the representation of these designs would allow an overview of the course and thus, could lead the teacher to think about the course, from four aspects:

1) Guidance and Support-course structure and timetable e.g. course calendar, study guide, tutorials;

2) Content and activities-course materials, prior experience, learners-generated content, e.g. reading, DVDs, podcasts, labs;

3) Communication and collaboration-dialogic aspects of the course, interaction between learners and tutors-course;

4) Reflection and demonstration-internalization and reflections, e.g. text questions, blogs, e-portfolios, formative or summative assessment.

Naming the aspects defined by Conole (2013) as axes, axis 1 being composed of four components and the others with five components each, we identified (Figure 1) that the discipline of Health Education presented a profile focusing on the aspects of Guidance and Support, Content and Activities, as well as Communication and Collaboration.

\section{Course Description-Applying the Model}

The Health Education course is offered semiannually for forty hours, for students in the health area.

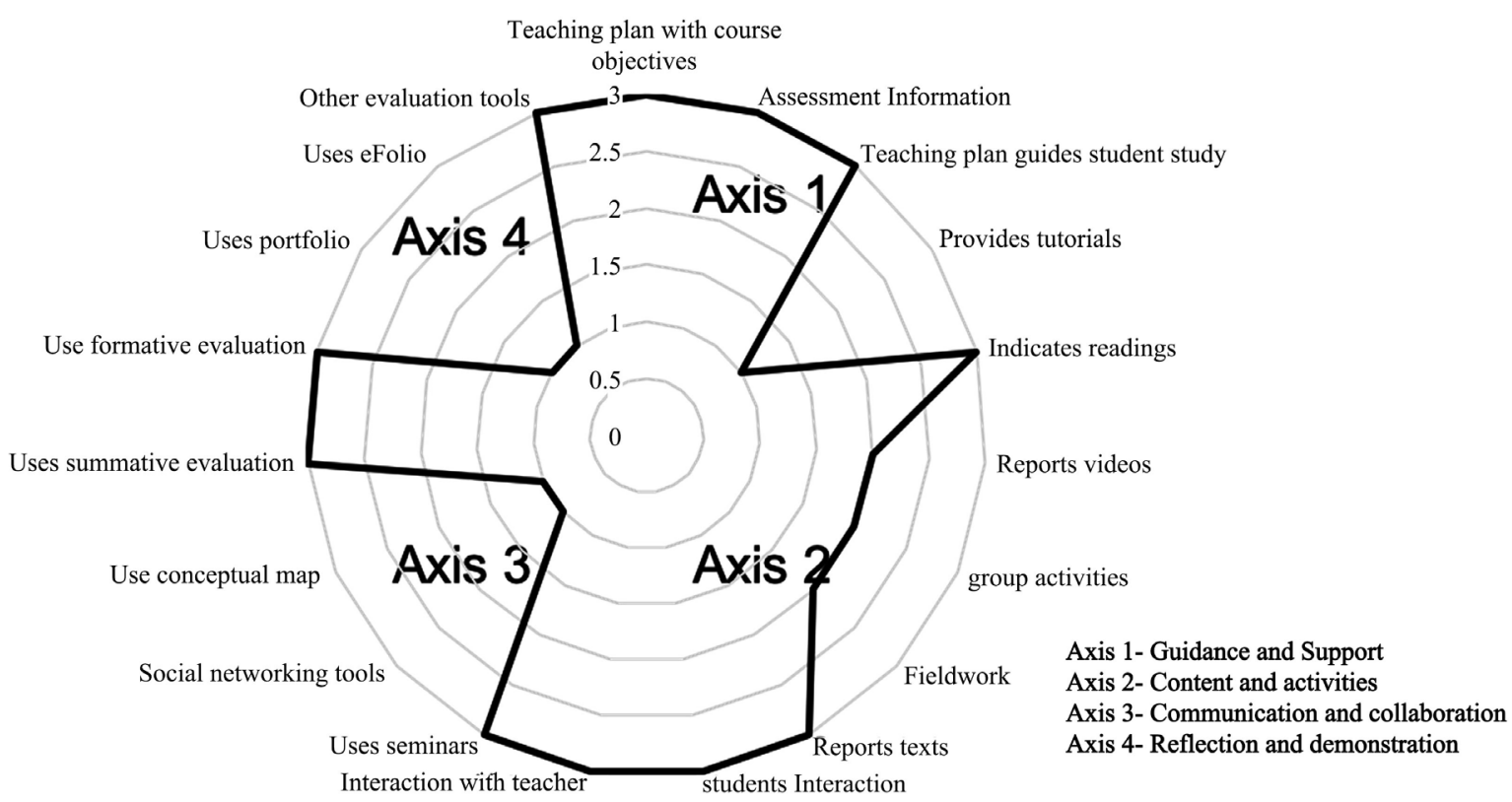

Figure 1. Profile of the course of health education. 
The general objective of the course is to enable the student to understand and act with the expanded concept of health education.

The structure of the discipline is divided into four fundamental parts:

1) Theoretical reference on health education, where we deepen the concept of health education and its applicability.

2) Discussion of the main diseases that affect the population, contextualizing the local reality of the city and the state.

3) Methodological reference to structure an educational product, at that moment we approach the assumptions of neurolinguistics in communication, the exploration and use of the five senses and the way information is captured both verbal and nonverbal, and personality structure, as a tool for expansion and structuring of communication.

4) Making and validating the educational product. At this moment, based on the theoretical framework, creativity is used to create an educational product with a view to working on the main diseases or diseases of the population already listed in the previous moment.

The course plan is delivered at the beginning of the semester and discussed with the students; however each class content emerges according to the demand of the previous class and the moment experienced by the class being worked through scientific articles, videos, films, experiences sensory, group dynamics. In our experience of almost ten years, there was no repetition of the same sequence.

Throughout the semester, the subjects are worked on along the same time, the student makes a self-evaluation as a human being, educator, and professional future.

The student is asked to choose a grievance or illness and for such to structure an applicable educational resource to the target public. At the end of the semester the EDUCATIONAL RESOURCES FAIRS are set up, where the student presents the educational product, fruit of the semester's work, and is evaluated by a panel composed of inside and outside professors, with the purpose of validating the product. This particular fair is already in its sixth edition. Below are some photos of the event (Figures 2-5).

For the development of the educational product the CTM3 method was applied, developed by Dr. Almira Alves dos Santos, this method contains the following stages: Design of the educational product, theoretical reference and methodological reference, the latter is based on 3 theories that are described below:

\section{Structure of the personality}

Transactional Analysis was created in 1956 by the psychiatrist Eric Berne (Kertész, 1987). He proposes a personality structure composed of three parts-Parent Ego State, Adult Ego State and Child Ego State. The Ego States represent the way we behave depending on the thoughts and emotions of the moment, when we communicate we are acting in function of one of these three structures, which is active in us, each one with different characteristics, and different in each person, This is due to the life experience itself, its motivations, its longings, its blockades and all previous structure of life, from conception, intrauterine life to the present moment. 
The Parent Ego State represents the rules, norms, limits, care, attention and learning acquired from our parent figures (father, mother, teachers, uncles, grandparents, etc.) teach us right, wrong, how we should act and in what to believe, in each individual there is an "inner parent," it also represents the patterns we have learned throughout our lives.

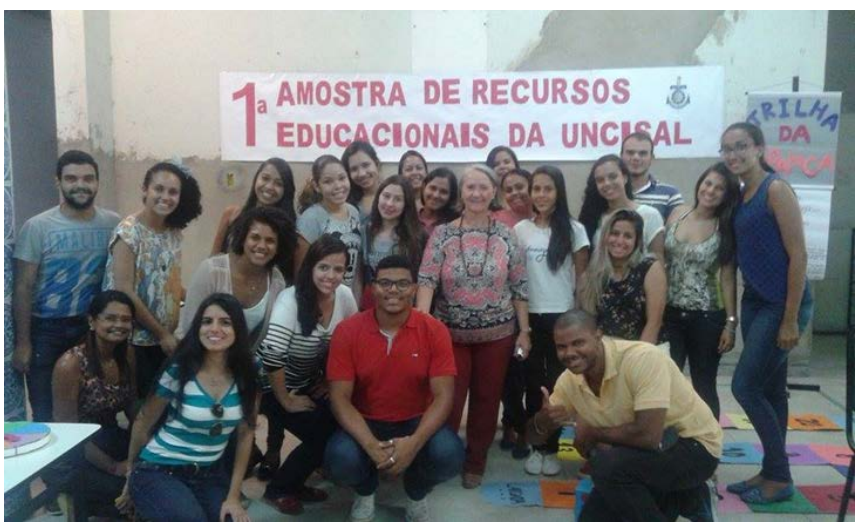

Figure 2. First Educational Resource Fair-June 2015.

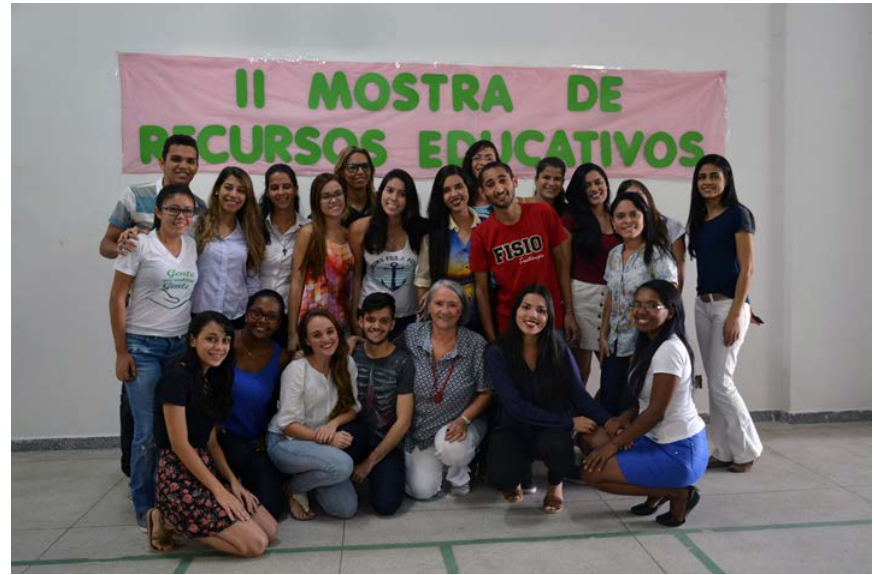

Figure 3. Second Educational Resource Fair-June 2016..

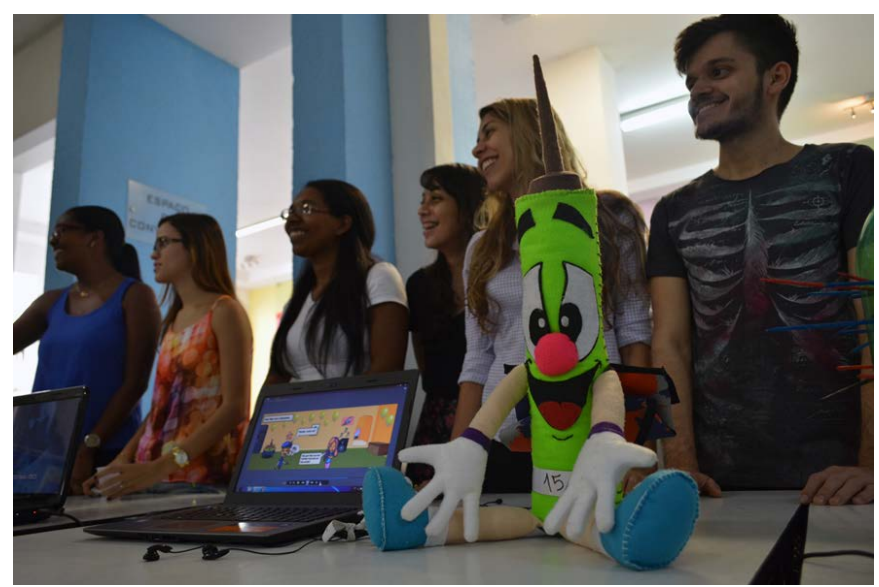

Figure 4. Students exposing Educational Resources during the Fair. 


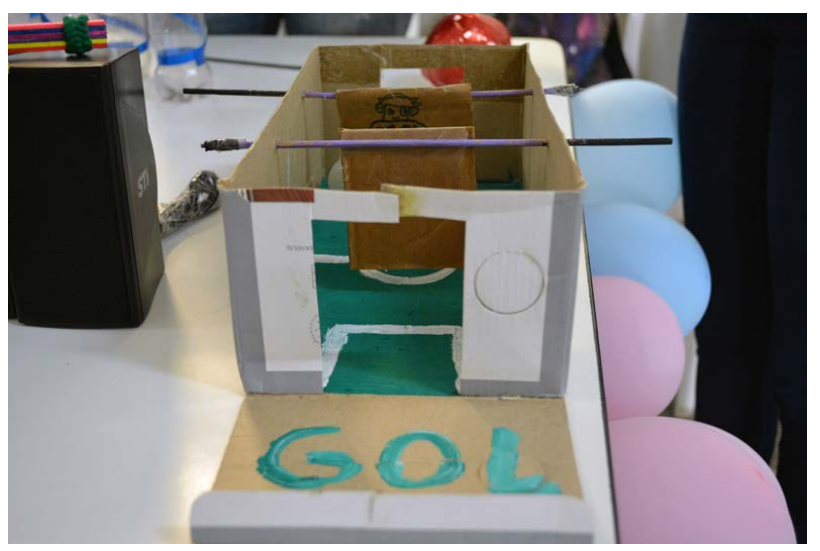

Figure 5. Educational resource exhibited in the fair to be worked with low income communities.

The Adult Ego State represents logical thinking, reasoning, it is as if a computer is implanted in each individual. In the State of Adult Ego there is no room for emotions, it is pure rationality, in which information is analyzed and processed in a clean and purely rational way.

The Child Ego Stateis responsible for joy, pleasure, naturalness, creativity, spontaneity, responsible also for fantasy. It is the reactivation of the child that we were and in it the principles of the child are revived.

It would be ideal if we had availability of the three structures whenever they were requested in the moments of interaction, but this is not the case throughout our lives, due to our experiences and social interactions, we structure and strengthen an ego state more than the other, we can, for example, have $50 \%$ of the Father Ego State, 25\% Adult and 25\% Child, so when the communication is intended for the Child ego state, there is no desirable availability, and communication may not if so, with other similar situations.

Based on this principle, it is important that we can initially determine the most available Ego state in the individual or group that we want to communicate. Thus, we can make complementarity in communication. However, it is not always easy to make this diagnosis, so it is safer to structure our communication always using the three states of Ego, because one of them will surely meet the state of availability of our interlocutor.

\section{Exploration of the senses}

We are made up of millions of cells to capture the information that surrounds us, from which we have our senses (auditory, visual, olfactory, synesthetic and gustatory) and each individual has one of the most available senses to capture information, similar to the states of Ego, individuals also have different percentages of sense availability. Some are more auditory, some more synesthetic, and so on, it is said that men, in general, are more visual than women.

If we know the availability of each direction in individuals and/or groups greatly facilitates the structuring of our communication, because we will pay more attention to the one of greater availability. However this is not the case, we will communicate in a "blind" way, without a previous diagnosis of these as- 
pects. It remains for us to use all our "ammunition" to communicate with all our senses, thereby ensuring that communication becomes more efficient.

\section{Neurolinguistic Programming (NLP)-Anchors structuring}

Another tool that we can use is the anchor, one of the theoretical assumptions of NLP, described by O'Connor \& Seymour (1995: p. 35) as: "a stimulus that makes us evoke a previous experience".

It is important to consider how we communicate in health, if we are communicating with just one individual or with groups, communities, having this parameter in mind we can then use all the artifacts to achieve our goals: to do health education efficiently.

\section{Exploring the senses-How to work}

The way in which we work the exploration of the senses occurs through films and videos which allows the student to perceive his own way of apprehending the world. For each sense becomes explicit and clear the perception of the most available sense, for some the auditory, others visual, kinesthetic and thus self-perception occurs for each student.

Another way is through shared feeding, where the student is blindfolded and some foods are offered, for some it is a unique discovery.

\section{Personality structure-How to work}

Through a questionnaire, containing 50 closed questions about the daily life of the students, how they behave and act in certain situations, is that we establish the egogram, which is an instrument that identifies the percentage of each ego state used by the student to communicate and interact. Each question corresponds to a specific State of Ego and the measurement is given through the answers corresponding to each State of Ego presented. Thus, it is determined which State of Ego is most present in the structure of each student. While the student is able to understand how this process happens to him, he will also understand that this process also occurs with the audience he will work with and the importance of inserting these elements in each resource.

\section{Anchors structuring-How to work}

The anchors are worked through films and recovery of the students' own experiences. They are asked to comment on an important moment in life, people, moments and events that have marked their lives. In this temporal space of the discipline the students already perceive what kind of ancora they have established if in function of an auditory experience through a music, word or speech, or through a perfume, smell, sound, of a synesthetic event and giving the exchange of experience.

Usually the experiences are carried out collectively and the experience may or may not be shared in the group. When the student feels comfortable, and usually this occurs, the experience is discussed which brings great moments with diverse symbology and great learning.

\section{Results}

The learning teaching process has a dynamicity capable of surprising us every 
day, every moment. The exchange potential is immense and the results, amazing. We quote some of the students' comments:

"The discipline is a process that involves knowledge and personal growth in the proposal of humanization of the future professional, allowing the person a whole view of the individual, seeking to understand their needs in a psycho-social context. In this method we are also taught that the health professional should be responsible for preventing, treating and promoting health and for this he must educate, always attentive to the language of each person, so that he can transmit the desired message. Therefore, the concern of educational resources that come to sharpen the five senses, since it is an enriching method which applies a diversified education. Thus, this discipline deconstructs the technicity thinking to build a humanization based on ethical and moral principles. That focus not only the human being affected but also the person in need of something or someone". Student A (2015).

"This discipline brought many social themes that were discussed in class. The class was totally integrated with students from the medical course as well as other courses. This type of integration is usually not seen, and it is uncommon mainly with the medical course in relation to other courses. One of the articles I liked the most was of a teacher from Harvard who gave tips on how to be happy, presenting actions simple to implement. So, we realized because the rush of our daily lives running around and mainly with the busy schedule at the university, we do none of those tips. This was a time when the entire class had the chance to reflect on our routine and this was very good. The material also brought many dynamics, one of the best was when we put a blindfold and without knowing what it was, we ate some food that the professor served on the plate, at times we knew what it was only by the taste of it and thus stimulating that particular sense. Then still with our eyes blindfolded, we hugged the people in the group without even knowing who it was, but each touch had a different smell and a different way of touching and hugging. This was a very important activity because the group had the chance to have a moment to approach one another regardless of their course, color and etc. It was a wonderful moment especially for those who needed a hug and surely the professor had a maternal touch, the type of strong and kind embrace of comfort. It is important to highlight also the educational resources fair that was a wonderful assignment given by the professor, in which we exposed the biological risks that we are often exposed to ourselves, may it be for the lack of a simple hand washing as well as for not properly bushing after consuming food. I gained a lot of knowledge as I transmitted knowledge through my subject of choice. I really liked the discipline and I will miss it. I will bring to life the teachings transmitted by Professor Almira Santos, from her teachings about ego states to tips on how to do academic work'. Student B (2018).

"The subject of health education is very good, and I recommend that people take this class as well. We have learned a LOT, now we realize the importance of the word education, respect and empathy for others (particularly for the pa- 
tient). Learning about all the theories seen in the room was very good and made us see the world around better. All the moments were very enriching. Our professor, Almira Alves, makes sure that you participate in all the classes, however, I do not like to participate much, mainly because sometimes I am afraid of what to say, afraid of not being 'right'. But our professor listens to all the students, what you said may be wrong, but she listens silently to your point of view and does not criticize. Finally, I would like to thank the professor and for giving so much of herself and her time and transmitting so much knowledge to the class. I highly recommend people to take this health education class!!!". Student $C$ (2018).

This integrated model of discipline allows the student an understanding of communication and learning processes, since they themselves experienced the elements that guide in practice, a way of learning. Having been experienced, they incorporate and may be able to act in the same way when acting in a community.

\section{Conclusion}

The learning teaching process has a dynamicity capable of surprising us every day, every moment. The exchange potential is immense and the results, amazing.

The theories of learning allied to the use of technologies, have brought components that have helped in "learning", as well as the ways to make learning happen.

This process is best when shared in its entirety, where the teacher and the student complement, interact and participate actively in the improvement of the quality of life of individuals.

For future studies, we intend to carry out a research where we can compare the teaching learning process of students who participated in the discipline with students who did not participate. This is possible because among nine of the ten courses offered by the University, this discipline is offered as elective. In this way we can evaluate the effectiveness of the method.

\section{Conflicts of Interest}

The authors declare no conflicts of interest regarding the publication of this paper.

\section{References}

Skinner, B. F. (1968). The Technology of Teaching. New York: Appleton-Century-Crofts.

Harasim, A. L. (2012). Learning Theory and Online Technologies. New York: Routledge/Taylor\& Francis.

Picciano, A. G. (2017). Theories and Frameworks for Online Education: Seeking an Integrated Model. Online Learning, 213, 166-190.

Atkinson, R. C., \& Shiffrin, R. M. (1968). Human Memory: A Proposed System and Its Control Processes. In K. W. Spence, \& J. T. Spence (Eds.), The Psychology of Learning and Motivation (pp. 89-195). New York: Academic Press. 
https://doi.org/10.1016/S0079-7421(08)60422-3

Gardner, H. (1983). Frames of Mind: The Theory of Multiple Intelligences. New York: Basic Books.

Lin, L., Crnton, P., \& Bridglall, B. (2005). Psychological Type and Asynchronous Written Dialogue in Adult Learning. Teachers College Record, 107, 1788-1813. https://doi.org/10.1111/j.1467-9620.2005.00542.x

Quintas-Mendes, A., \& Wyszomirska, R. M. A. F. (2018). Education and Teacher Training in the Context of Online Distance Education. Revista Tempos e EspaçosemEducação, 11, 93-112. https://doi.org/10.20952/revtee.v11i01.9895

Brasil (2007). Ministerial Order No 3.019 .

http://bvsms.saude.gov.br/bvs/saudelegis/gm/2007/pri3019_26_11_2007.html

Brasil (2008). Ministerial Order $N^{o} 1.802$. http://bvsms.saude.gov.br/bvs/saudelegis/gm/2008/pri1802_26_08_2008.html

Moraes, B. A., \& Costa, N. M. S. (2016). Understanding the Curriculum, the Light of Training Guiding Health in Brazil. Journal of School of Nursing-University of São Paulo, 50, 9-16. https://doi.org/10.1590/S0080-623420160000300002

Fernandes, C. R., Farias Filho, A., Gomes, J. M. A., Pinto Filho, W. A., Cunha, G. K. F., \& Maia, F. L. (2012). Competency-Based Curriculum in Medical Residency. Revista Brasileira de Educação Médica, 36, 129-136. https://doi.org/10.1590/S0100-55022012000100018

Keller-Franco, E., Kuntze, T. D., \& Costa, L. S. da. (2012). Curricular Innovation in Health Professionals Formation. Revista e-Curriculum, 8, 1-14. http://revistas.pucsp.br/index.php/curriculum/article/view/10853/8054

Davini, M. C. (1983). Currículo Integrado. OPAS. http://lagarto.ufs.br/uploads/content_attach/path/11340/curriculo_integrado_0.pdf

Conole, G. (2008). New Schemas for Mapping Pedagogies and Technologies. Ariadne Article. http://www.ariadne.ac.uk

Conole, G. (2013). Designing for Learning in an Open World (pp. 147-151). New York: Springer Science and Business Media. https://doi.org/10.1007/978-1-4419-8517-0

Kertész, R. (1987). Análise Transacional ao Vivo. São Paulo: Summus.

O’Connor, J., \& Seymour, J. (1995). Introdução à programação neurolinguistica. São Paulo: Summus. 